\title{
Illicit Trafficking in Narcotic Drugs and Their Analogues Using Computer Technology: A Criminal Law Study
}

\author{
OLEH OMELCHUK ${ }^{1}$, VOLODYMYR KOPANCHUK ${ }^{2}$, BOHDAN ORLOVSKYI ${ }^{3}$, \\ LILIIA SHEKHOVTSOVA ${ }^{4}$, KATERYNA YANISHEVSKA ${ }^{5}$, OLENA KOPANCHUK ${ }^{6}$ \\ ${ }^{1}$ Criminal Law and Procedure Department, LEONID YUZKOV KHMELNYTSKYI UNIVERSITY OF MANAGEMENT \\ AND LAW, UKRAINE. E-mail: oleg.omelchuk@ukr.net \\ ${ }^{2}$ Criminal Law and Procedure Department, LEONID YUZKOV KHMELNYTSKYI UNIVERSITY OF MANAGEMENT \\ AND LAW, UKRAINE. \\ ${ }^{3}$ Criminal Law, Criminal Procedure and Criminalistics Department, ODESSA I.I. MECHNYKOV NATIONAL \\ UNIVERSITY, UKRAINE. \\ ${ }^{4}$ Criminal Law and Justice Department, ZAPORIZHZHYA NATIONAL UNIVERSITY, UKRAINE. \\ ${ }^{5}$ Criminal Legal Disciplines and Legal Proceedings Department, SUMY STATE UNIVERSITY, UKRAINE. \\ ${ }^{6}$ Education Center, NATIONAL UNIVERSITY OF CIVIL PROTECTION OF UKRAINE, UKRAINE.
}

\begin{abstract}
Modern negative trends in drug-related crime on the Internet, the peculiarities of its existence and reproduction in the global network dictate the need for a further deeper research of the criminological and legal characteristics of the crimes under consideration and the grounds for criminalizing the drug distribution method. The public danger of drug-related crime on the Internet is expressed in the fact that at present the computerization of the population is gaining momentum, computer technology has become a necessity, and the Internet has become public, where a large amount of information about narcotic drugs, the possibilities of their manufacture, acquisition, the sale is concentrated; their unusual properties are described, etc. The authors studied in detail the level, structure and dynamics of drug trafficking, as well as its criminal law regulation and proposed a mechanism for preventive measures. The authors also conducted a study and, based on the responses of 108 respondents, identified the most effective preventive measures.
\end{abstract}

Keywords: illicit trafficking, criminal, drugs, law.

JEL Classification: K13, K42, 017

Received: 19 March 2021

Accepted: 6 April 2021 


\section{Introduction.}

Drug addiction, the spread of drugs and drug crime poses a threat to the state and public security and lead to the degradation and extinction of all humanity (Haksama et al., 2020; Umerzhanovich et al., 2020). The forms and methods of drug-related crimes are continually improving, along with scientific and technological progress and social relations development (Luong, 2020; Omelchuk et al., 2020; Stippel and Serrano-Moreno, 2020).

The public danger of crimes in the sphere of illicit trafficking in narcotic drugs and their analogues, committed using computer technologies (the Internet), is determined, along with other signs, by an increase in the criminality of the information space of the global network, the number of users of which in the world is 4.66 billion (+7.3\%) in January 2021 (Kemp, 2021) and 27.46 million internet users in Ukraine (+5.7\%) in January 2020 (Kemp, 2020), influencing various spheres of society and causing inappropriate social and criminal behaviour of groups of people or individuals. This is due to the general availability, openness of the global network, and insufficient legal regulation of its activities.

In January 2021, Deputy Interior Minister O. Gogilashvili noted that almost all drug trafficking went to the Internet, as well as the calculation of such transactions (Press centre of the MIA, 2021).

According to the World Drug Report (United Nations, 2020), world drug consumption is significant (Fig. 1), Ukraine occupies an insignificant place in the overall ranking of countries (Fig. 2), but the problem of drug crimes is also typical for it.

Figure 1. Global Annual drug seizures by drug type (United Nations. World Drug Report, 2020)

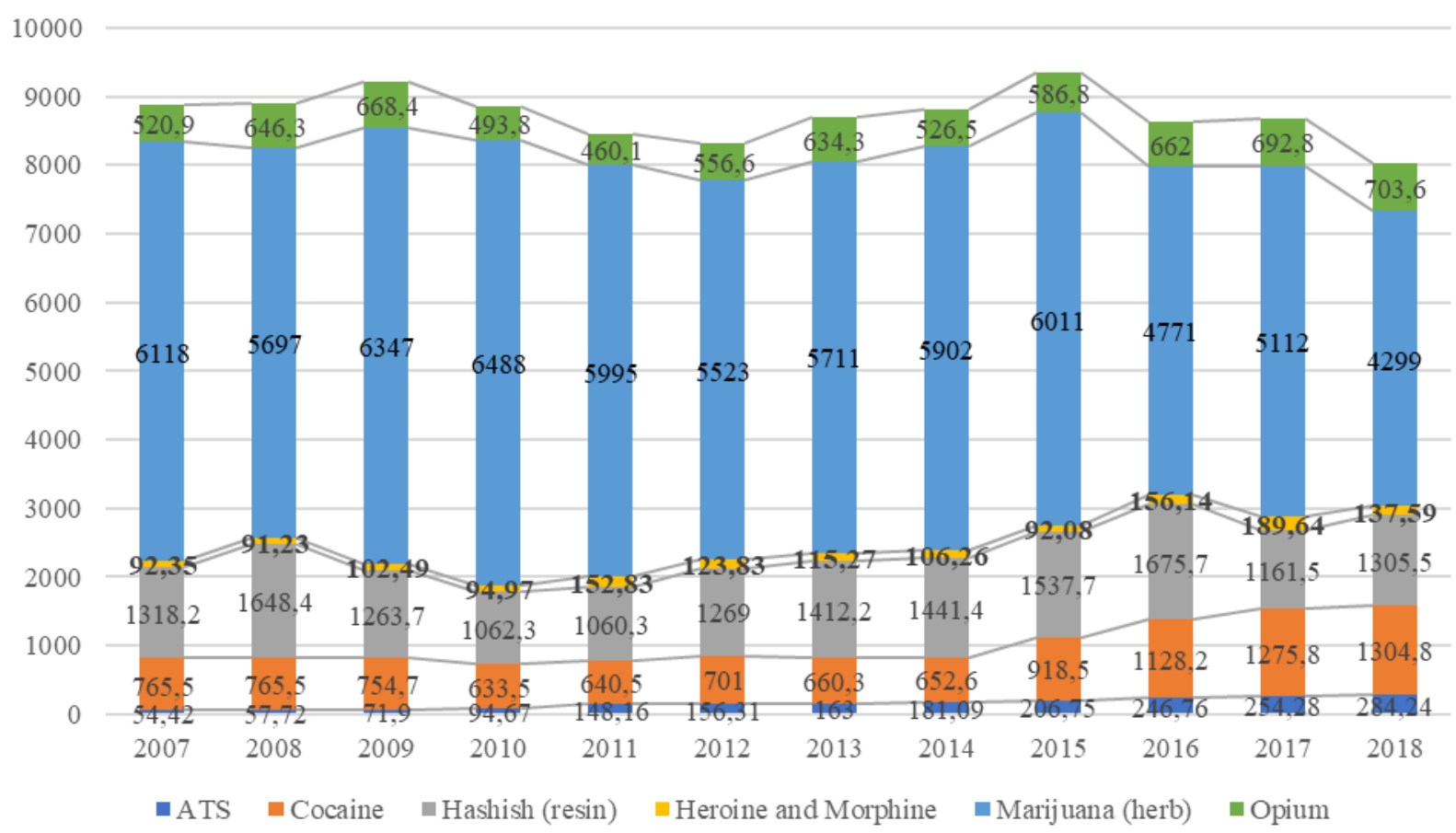

The current trend in drug-related crime is the expansion of the spread of drug-related crimes committed using the Internet, increasing the demand for drugs through search engines. This is what proves the relevance of the study and the need for further development of theoretical provisions and proposals of a practical nature in the field of combating drug trafficking using computer technologies (Internet). 
Figure 2. Annual drug seizures by drug type in Ukrain (United Nations. World Drug Report, 2020)

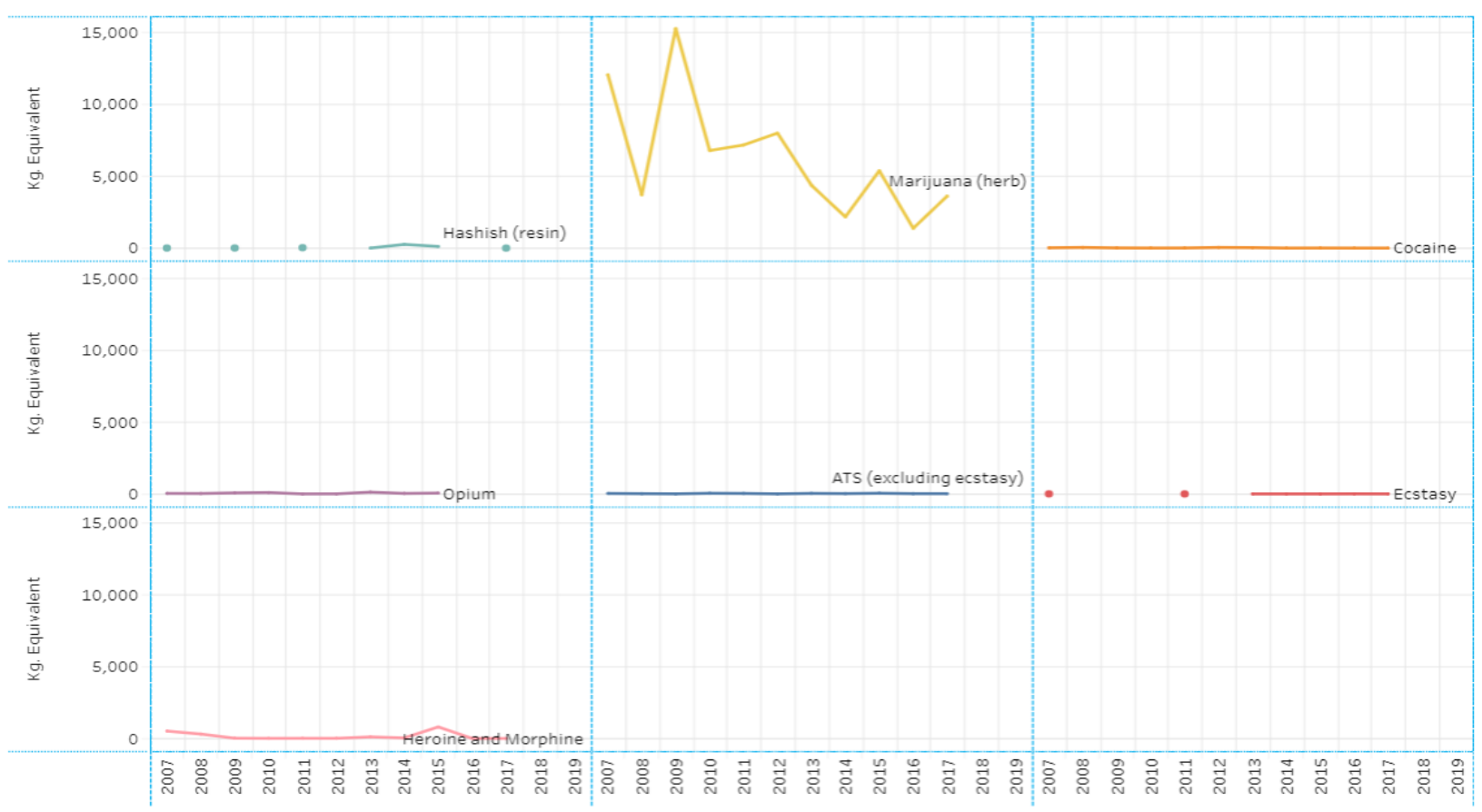

\section{Research methods.}

The methodological basis of the research is the dialectical method. In the course of the study, general methods of cognition (analysis and synthesis, generalization, deduction, comparison, analogy) and private, scientific methods were used: comparative-legal, systemic and structural analysis of documents, statistical analysis, survey, expert assessment.

From the standpoint of a systematic approach, crime in the sphere of illegal drug trafficking on the Internet is a social system, the system-forming feature of which is a particular type of human activity - criminal activity affecting two areas: on the one hand, it is drug trafficking, on the other, computer technology (Internet).

\section{Theoretical aspect.}

\subsection{Level, structure and dynamics of drug trafficking using computer technologies (Internet).}

Crime in the sphere of illegal drug trafficking on the Internet is a relatively new phenomenon that appeared at the end of the 20th century with the Internet's development. This concept is inextricably linked with the concept of crime in the sphere of illegal drug trafficking (drug crime). The broader concept is a crime in general. At the same time, crime in the sphere of unlawful drug trafficking on the Internet is distinguished by its distinctive features, generic and specific, which make it possible to speak of it as an independent type of crime, which is the criminal activity of persons committing crimes in the sphere of illegal drug trafficking using computer technologies. (Internet) (Fig. 3).

The degree of public danger of drug-related crime on the Internet is higher than the degree of public danger of drug-related crime by persons who commit such acts in other ways. This circumstance is since the components of public danger are increasing: its ability to generate socially negative consequences is higher, and with an increase in the proportion of persons committing such acts using the Internet, and, accordingly, Internet resources, its precedent nature rises. The use of the Internet facilitates the search for potential clients for illegal drug transactions, the involvement and inducement to use drugs, the imposition of the subculture of drug addicts and other illegal activities. Besides, drug-related crime on the Internet is a relatively widespread phenomenon, 
represented by a significant number of committed criminal offences. And this is only the Internet, and there is also DarkNet, which is an anonymous network and thus contributes to criminal activity.

Figure 3. Features of a drug crime as a system

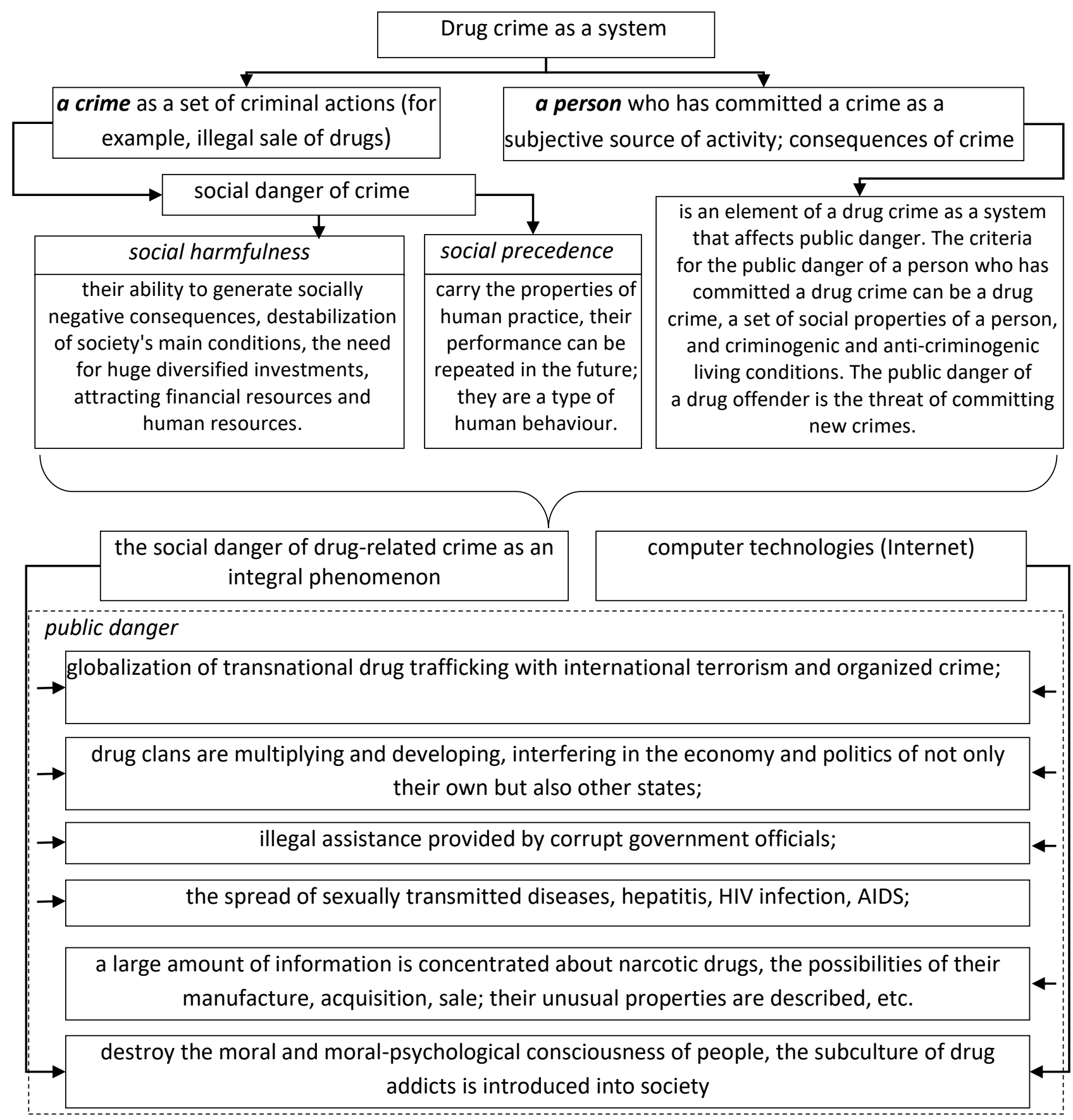

Thus, crime associated with illegal drug trafficking on the Internet can be defined as a socially dangerous, social, relatively massive criminal law phenomenon that exists at a specific time in a particular territory, and consists of drug crimes that form a joint criminal activity of persons, their committed using computer technologies (Internet).

\subsection{Law regulation of illicit trafficking in narcotic drugs and their analogues.}

Illicit trafficking in narcotic drugs, psychotropic substances and precursors - acts of cultivation of plants included in the List of narcotic drugs, psychotropic substances and precursors, development, production, manufacture, storage, transportation, shipment, purchase, sale, import into Ukraine, export from the territory of Ukraine, transit through the territory of Ukraine, use, destruction of 
narcotic drugs, psychotropic substances and precursors, carried out in violation of the legislation on narcotic drugs, psychotropic substances and precursors (Law of Ukraine, 1995).

In Ukraine, the State Service of Ukraine for Medicinal Products and Drug Control deals with state regulation and control in trafficking in narcotic drugs, psychotropic substances, precursors and combating their illicit trafficking.

The primary legal documents of Ukraine are:

Laws of Ukraine

"On narcotic drugs, psychotropic substances and precursors",

"On licensing of economic activities",

"On the basic principles of state supervision (control)",

"On medicines",

"On measures to combat illicit trafficking in narcotic drugs, psychotropic substances and precursors and their abuse".

Resolutions of the Cabinet of Ministers of Ukraine

from 06.04.2016 № 282 "Some issues of licensing of economic activities for the cultivation of plants included in Table I of the list of narcotic drugs, psychotropic substances and precursors, approved by the Cabinet of Ministers of Ukraine, development, production, manufacture, storage, transportation, acquisition, sale (release), import into the territory of Ukraine, export from the territory of Ukraine, use, destruction of narcotic drugs, psychotropic substances and precursors included in the specified list ";

from 13.05.2013 № 333 "On approval of the Procedure for acquisition, transportation, storage, release, use and destruction of narcotic drugs, psychotropic substances and precursors in health care facilities";

from 03.06.2009 № 589 "On approval of the Procedure for carrying out activities related to the circulation of narcotic drugs, psychotropic substances and precursors, and control over their circulation";

from 26.10.2008 № 1026 "About the statement of Conditions of prevention of theft of the plants included in the list of narcotic drugs, psychotropic substances and precursors".

Penalties of the Ministry of Health

from 07.08.2015 № 494 "On some issues of acquisition, transportation, storage, release, use and destruction of narcotic drugs, psychotropic substances and precursors in health care facilities";

from 19.07.2005 № 360 "On approval of the Rules for prescribing medicines and medical devices, the Procedure for release of medicines and medical devices from pharmacies and their structural units, Instructions on the storage, accounting and destruction of prescription forms" with changes and additions ;

from 27.03.2012 № 200 "On the procedure for substitution maintenance therapy for patients with opioid dependence".

from 22.01.2018 № 109 "On approval of the unified form of the act, which is based on the results of planned (unscheduled) measures of state supervision (control) for compliance by the business entity with the licensing conditions of economic activities for the cultivation of plants included in table I list of drugs means, psychotropic substances and precursors approved by the Cabinet of Ministers of Ukraine, development, production, manufacture, storage, transportation, acquisition, sale (release), import into the territory of Ukraine, export from the territory of Ukraine, use, destruction of narcotic drugs, psychotropic substances and precursors, included in the specified list and the form of the administrative document".

In Ukraine, there is an administrative and criminal liability for illicit trafficking in narcotic drugs and their analogues. It should be noted that a person who voluntarily applied to a medical institution 
for a course of treatment for drug addiction is released from criminal liability. A person is released from administrative liability if he has voluntarily surrendered narcotic drugs or psychotropic substances that he had in small amounts.

Administrative responsibility. Article 44 of the Code of Ukraine on Administrative Offenses provides for administrative liability for illegal production, acquisition, storage, transportation, a shipment of narcotic drugs or psychotropic substances without the purpose of sale in small amounts, namely: a fine of 25 to 50 non-taxable minimum incomes; public works for a period of twenty to sixty hours; administrative arrest for up to fifteen days.

The amount of these substances is determined by order of the Ministry of Justice of Ukraine dated August 1, 2000, № 188 "On approval of tables of small, large and enormous sizes of narcotic drugs, psychotropic substances and precursors in illicit circulation."

Criminal liability. Section XIII of the Criminal Code of Ukraine is also devoted to the issue of committing crimes in the field of drug trafficking and bringing perpetrators to criminal responsibility.

Conventionally, such crimes are divided into:

- crimes related to illicit trafficking in narcotic drugs and other objects dangerous to the health of the population (Articles 305-307, 309-311 and 320 of the Criminal Code of Ukraine);

- crimes related to illegal possession of drugs, as well as equipment intended for their manufacture (Articles 308, 312, 313, 318 and 319 of the Criminal Code of Ukraine);

- crimes related to the illicit use of narcotic drugs and narcotics (Articles 314-317 of the Criminal Code of Ukraine).

According to Article 309 of the Criminal Code of Ukraine, illegal production, manufacture, acquisition, storage, transportation or shipment of narcotic drugs, psychotropic substances or their analogues without the purpose of sale are punishable: a fine of 50 to 100 non-taxable minimum incomes; correctional work for up to two years; arrest for up to six months; restriction of liberty for up to three years; imprisonment for up to three years.

The same acts committed repeatedly or by prior conspiracy by a group of persons or a person who has previously committed one of the crimes provided for in Articles 307, 308, 310, 317 of the Criminal Code of Ukraine, or if the subject of such actions were narcotic drugs, psychotropic substances or their analogues large amounts are punishable by imprisonment for a term of two to five years.

The actions provided for in parts one or two of this article, committed with the involvement of a minor, as well as if the subject of such actions were narcotic drugs, psychotropic substances or their analogues in huge amounts, - shall be punishable by imprisonment for a term of five to eight years.

\section{Main results of the study.}

The authors believe that prevention occupies an essential place in the system of measures to organize counteraction to crimes in the sphere of illicit trafficking in narcotic drugs, psychotropic substances, and their analogues. It is precisely this that allows us to prevent mass criminal behaviour with all its negative consequences.

Given the variety of drug crime prevention measures, we consider it necessary to classify them according to the levels of impact or purpose: general (general social), special criminological and individual (Fig. 4).

Among the measures listed, it is essential to encourage the creation of anti-drug resources, since these resources increase the legal and drug literacy of the population, provide answers to common questions, and are also able to provide various assistance to their visitors. Anti-drug resources are currently much less abundant; alternative anti-drug activity, in the Russian-language version, is in a state of development and is represented by isolated and not always sufficient servers. On the contrary, Western space is quite densely filled with resources of various purposes and content - from 
government and international organizations' official servers to the servers of civil initiative movements.

Figure 4. Mechanism of preventive action against illicit drug trafficking

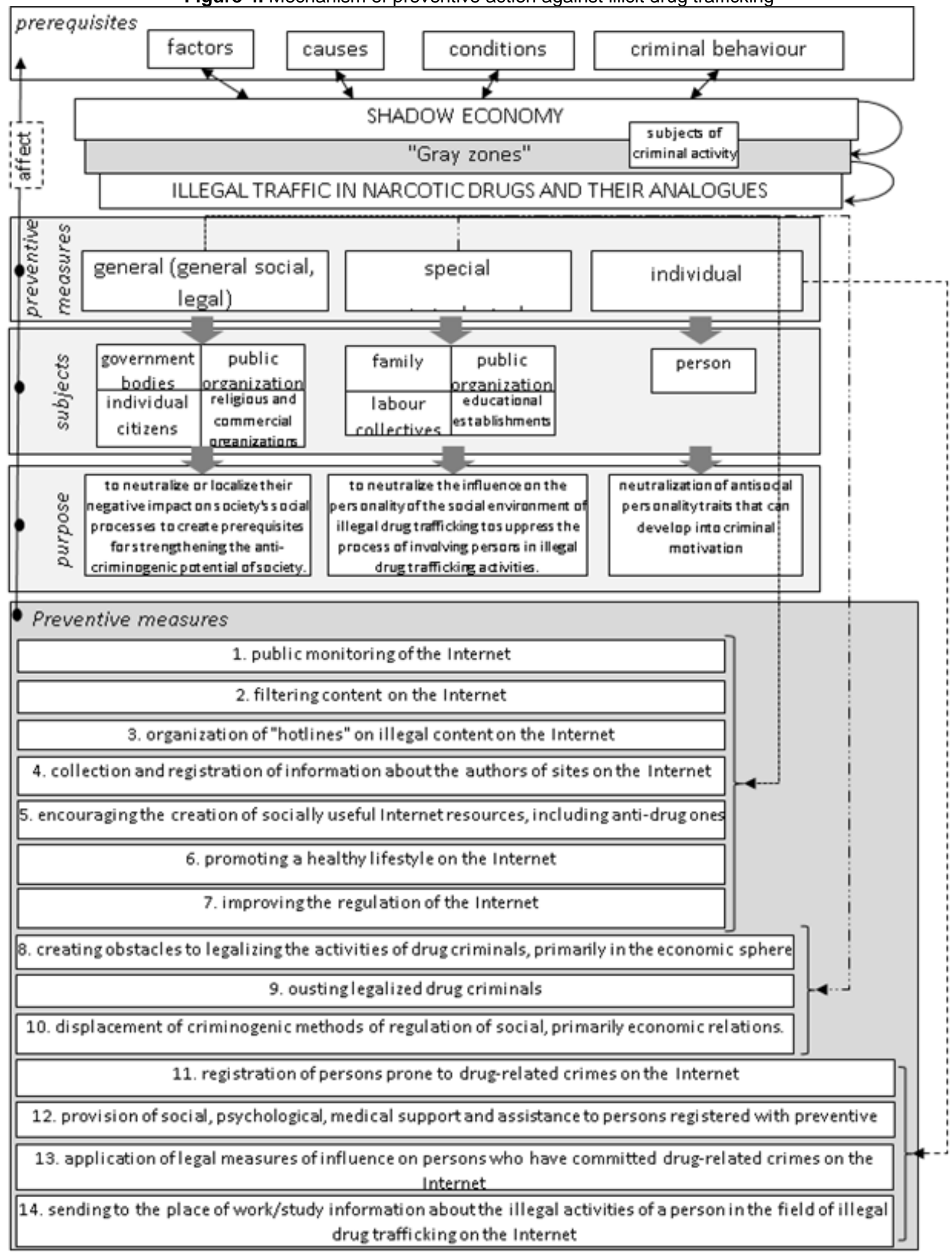

It should be noted that the Internet does not stand still and is constantly evolving; many sites of various topics are continually appearing. Now, due to the high prevalence of the World Wide Web, everyone can contribute to the development of the Internet and create their own website for drug 
prevention. Thus, the solution to this problem depends not only on the bodies that carry out the prevention of crimes in the field of illegal trafficking in narcotic drugs and their analogues.

The criteria for assessing the prevention of crime related to the illegal circulation of narcotic drugs and their analogues using computer technologies (the Internet) can be:

- the number of pro-drug sites on the Internet;

- the nature of information about drugs and their analogues posted on the Internet;

- the minimum time required to search for information on the acquisition, sale, manufacture of drugs through various search engines on the Internet.

Currently, in connection with the development and active penetration of almost all spheres of human activity of the Internet, its influence on the consumers of addictive substances (addiction addiction) becomes more and more tangible. The Internet space can be viewed as a social "cyberspace" - a kind of information and communication field formed by users interacting with each other and is characterized by almost unlimited freedom and anonymity of this information interaction. Since recently, methodological developments have appeared on the use of Internet resources in preventive work; it is possible to consider two areas of network activity that have different effects on crimes in illegal drug trafficking and their analogues: pro and anti-narcotic. Both of these areas have quite extensive network resources; a considerable part of them are concentrated in the Ukrainian-speaking space.

\section{Discussion: Evaluation of the effectiveness of the prevention of crime related to the illegal circulation of drugs and their analogues using computer technology.}

The criteria for assessing the prevention of crime associated with the illegal circulation of narcotic drugs and their analogues using computer technologies (the Internet) can be:

- the number of pro-drug sites on the Internet;

- the nature of information about drugs and their analogues posted on the Internet;

- the minimum time required to search for information on the acquisition, sale, manufacture of drugs through various search engines on the Internet.

To assess the possible effects of the proposed mechanism of preventive measures, the authors conducted a survey. The survey conducted by the authors showed the following results of the potential effectiveness of the proposed mechanism (Fig. 5).

The survey was conducted among 108 respondents, divided into 3 groups:

Group 1 - a person convicted of drug crimes group;

Group 2 -A person who is under preventive supervision of drug addicts;

Group 3 - an employee engaged in the fight against drug-related crimes.

For the purity of the experiment, the group had an equal number of 36 people; the gender ratio was 1: 1. Respondents were either given answers for self-completion or answered in the form of interviews.

The questionnaire contained only one question: rank the measures according to their effectiveness in descending order from 1 to 14 , where 1 is the most effective measure for preventing illegal trafficking in narcotic drugs and their analogues using computer technologies, 14 is the least.

The analysis showed that, according to the aggregate opinion of the participants in the process, the illegal circulation of narcotic drugs and their analogues using computer technologies: criminal law research, the TOP-3 of the most effective preventive measures include:

1. improving the regulation of the Internet;

2. public monitoring of the Internet;

3. filtering content on the Internet. 
Figure 5. Results of a survey of a group of respondents about the possible most effective preventive measures to prevent illegal traffic in narcotic drugs and their analogues using computer technology

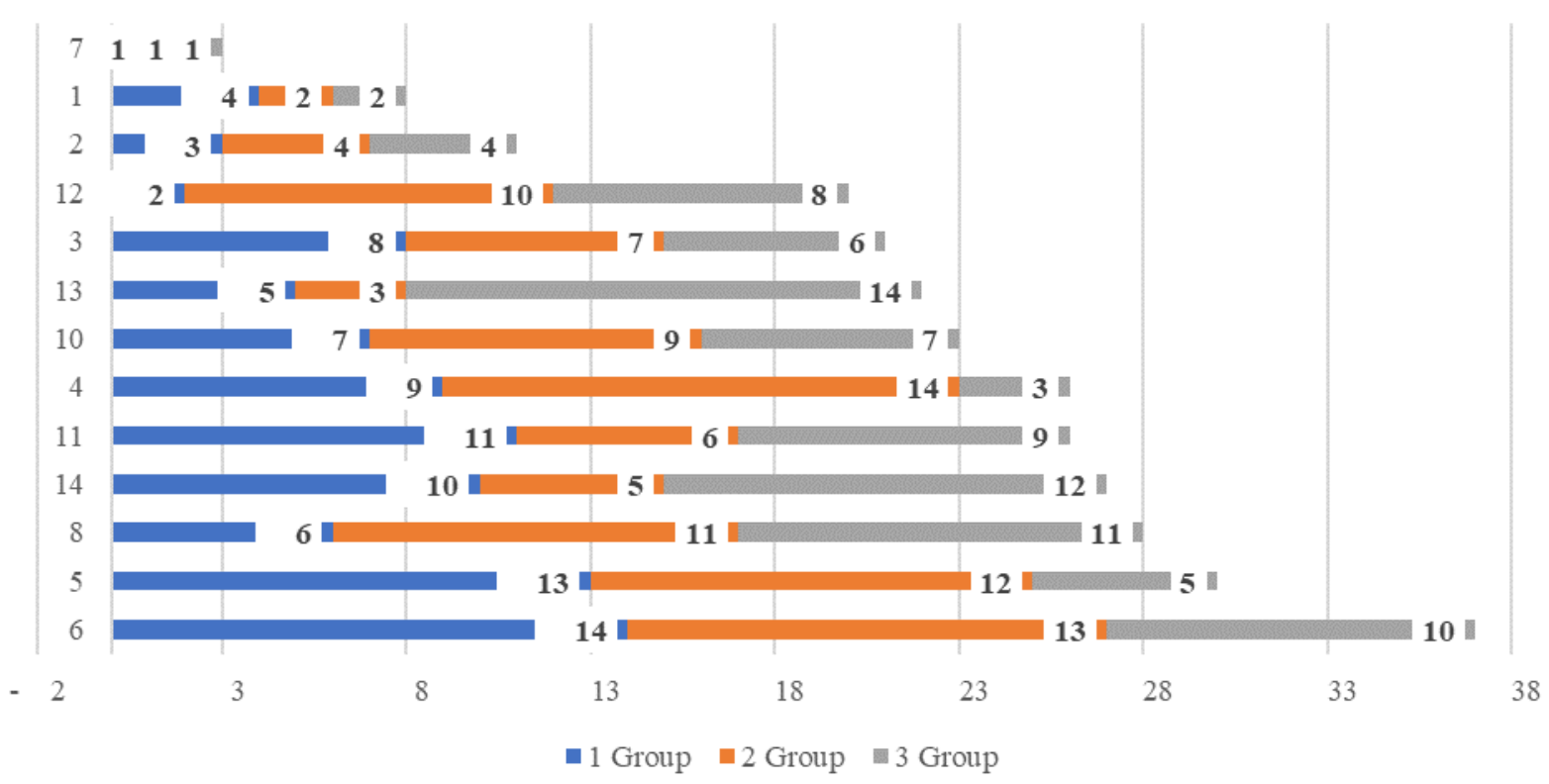

It should also be noted that in the aggregate, absolute leadership is given to general (general social, legal) preventive measures as the most effective.

\section{Conclusion.}

Thus, the study analyzed the prevention of crimes related to the illegal circulation of drugs and their analogues on the Internet, the result of which are recommendations for the introduction of constant monitoring of various Internet resources: control of newly created websites; revealing the facts of placing information banners; tracking the facts of dissemination of information using the Internet, for example, the mass mailing of emails or messages; checking information on social networks; analysis of data from chats, instant messengers, etc. services of the Internet.

Among the general measures for preventing drug crime on the Internet, the most effective is promoting a healthy lifestyle on the Internet, filtering content on the Internet, collecting and registering information about the authors of sites on the Internet.

\section{References}

1. Code of Ukraine on Administrative Offenses. Available at https://zakon.rada.gov.ua/laws/show/80731-10\#Text

2. Haksama, S., Farid Dimjati Lusno, M., Setyowati, A., Wulandari, A., Nugroho, B., Roesli, M., Hidayat, M., Rudianto, E., Khan, M.M., Sriram, S., Shedysni, S.N., Rifqo Hafidzudin Farid, M., Farid, A.F., \& Shedyta, S.Z. (2020). Criminal liability by the pharmaceutical industry on the use of precursors for illicit narcotics in Indonesia: A review. International Journal of Criminology and Sociology, 9(24), pp. 1782-1788.

3. Kemp, S. (2020). Digital 2020: Ukraine. Available at: https://datareportal.com/reports/digital2020-ukraine

4. Kemp, S. (2021). Digital 2021: Global Overview Report. Available at: https://datareportal.com/reports/digital-2021-global-overview-report

5. Law of Ukraine "On measures to combat illicit trafficking in narcotic drugs, psychotropic substances and precursors and their abuse" (1995). Available at:

https://zakon.rada.gov.ua/laws/show/62/95-\%D0\%B2\%D1\%80\#Text 
6. Luong, H.T. (2020). The organisational structure of transnational narcotics trafficking groups in Southeast Asia: a case study of Vietnam's border with Laos. Trends in Organized Crime, 23(4), pp. 385-411.

7. Omelchuk, O., Shekhovtsova, L., Bodunova, O., Lukasevych-Krutnyk, Y., Yanishevska, K. \& Kateryna Plutytska, K. (2020). Criminal-Legal and Criminological Research of Illicit Trafficking in Narcotic Drugs and their Analogues with the use of Computer Technologies. International Journal of Management, 11 (6), pp. 728-738.

8. Stippel, J.A., \& Serrano-Moreno, J.E. (2020). The coca diplomacy as the end of the war on drugs. The impact of international cooperation on the crime policy of the Plurinational state of Bolivia. Crime, Law and Social Change, 74(4), pp. 361-380

9. Stop drug chatbot. Press centre of the Ministry of Internal Affairs of Ukraine (2021). https://mvs.gov.ua/ua/news/27449_CHat_bot_Stop_narkotik_dopomig_zablokuvati_ponad_300 _narkokramnic_borotba_z_narkochumoyu_triva_Oleksandr_Gogilashvili.htm

10.The Criminal Code of Ukraine. Available at https://zakon.rada.gov.ua/laws/show/2341-14\#Text

11.Umerzhanovich, S.B., Khalelovich, F.A., Vladimirovna, S.N., Sericbaevna, T.S., Habilovna, S.K., \& Sabitovich, O.A. (2020). Criminal prosecution for organizing or maintaining dens for the consumption of narcotic drugs, psychotropic substances, their analogues and providing premises for the same purposes under the legislation of the Republic of Kazakhstan. International Journal of Criminology and Sociology, 9(29), pp. 2385-2397.

12.United Nations. World Drug Report, 2020. Available at:

https://wdr.unodc.org/wdr2020/index.html 